\title{
Proposed Motor Flueney Educational program and its Effect on Improving Some Basic Motor Skills in Physical Education
} Lesson.

\section{Ahir Muawad Mohamed Abdallah}

Department of School Sport, Faculty of Physical Education for Boys, Alexandria University, Egypt.

\begin{abstract}
The current research aims at designing a recommended program to increase the functional efficiency of the frozen shoulder in elderly male patients with type 2 diabetes and identifying its effects on improving the muscular strength of shoulder muscles on all directions, the range of motion of the frozen shoulder on flexion, extension and adduction movements, the degree of pain and the blood sugar. The researchers used the quasi-experimental approach (one-group design) with pre-, intermediate and post-measurements. Subjects $(n=8)$ were purposefully chosen from elderly males $(50$ 60 years) with frozen shoulder and type 2 diabetes who undergo treatment at Kafr Al-Shaikh Sports Club rehabilitation clinic. The researchers concluded that using physiotherapy with dynamic rehabilitation exercises increased the muscle strength of the working muscles of the shoulder joint in cases of patients of frozen shoulder with type 2 diabetes. Using physiotherapy with dynamic rehabilitation exercises range of motion of the shoulder joint in cases of patients of frozen shoulder with type 2 diabetes The recommended program led to significant improvements for pain and blood sugarThere are statistically significant differences on all the research variables in favor of the post-measurements. These improvements are due to the use of physiotherapy (thermal treatment) with rehabilitation exercises in cases of elderly people with frozen shoulder and type 2 diabetes.
\end{abstract}

\section{Introduction:}

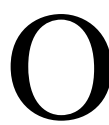

ur society is characterized by rapid changing and evolving, and this lead to contradiction between new ideas that go beyond previous negative ideas and develop renewable knowledge in the right place where the most interest and the most appropriate opinion, and that mere appearance of a new idea get out another idea contradict it, and so evolution and change is happening in idea type and level and without this progress does not happen; because we want to cope with civilization we had to take care of minds since childhood and planning their programs and provide educational experiences that make them more active to be educated. Then they could start contributing in community service (Mohamed 2003, p121). There is no doubt that physical education lesson has an important position in student educational process in physical, mental, and social aspects. It is one of fundamental basis for student's personality formation; where it develops cooperation spirit and law respect. Physical education lesson is an important and integral part of general education process (Al-Samarrai and AlSamarrai 2001, p 91)

Basic motor skills are a key requirement for most sport activities' skills, and failure to reach development and mastery of these skills acts as a barrier to the development of sports motor skills sports. Rateb (1999, p201) pointed out that basic motor skills stage which duration is between (2-7 years) occupies a distinctive importance for motor development stages, and it is the basis for acquisition of sport general and specific associated skills in the following development stages, particularly during late childhood and adolescence.

Researcher argues that these skills are the basics for pupil's motoric practice as is the foundation of majority of sports, so it's important that basic motor skills development programs are in its suitable position, and in pupils' early years, and that these skills should not be neglected by improper assumption that nature is capable of their development, although these skills development is somewhat due to genetic factors, but environment and related education and training play significant role in its development, so it is best to use the opportunity to develop these skills in suitable environmental condition in early classroom of primary education, where this stage is a vital and important stage of motor development in children. Abdul Hussein (1994, p17) emphasized that "it is important to provide good environmental conditions for pupils in order to give them the opportunity to develop basic motor skills; primary school pupil who did not appropriate care, encourage and favorable climate, will throw the ball or jump motor patterns do not exceed those of three years child ". There is no doubt that motor fluency programs contribute to achievement of motor education objectives for children; they help give the child ability to manage their bodies' efficiency in motor situations, coordination, agility, flexibility, balance, and accuracy in 
an effective and efficient manner through continuous adjustment to new positions (Ibrahim, 2008)

Motor fluency is one of main creative abilities, as it means "the ability to produce many ideas, where the responses are able to characterize pupil's ability as measured by the other ideas from pupil's fellows at a certain fixed unit of time" (El-Dewan 1999, p33). Giving attention to development of this ability among students is "important and inevitable", as its development leads to develop some physical abilities and provides an opportunity for excellence and innovation in various fields of life, including physical activity, which in turn reflects strengthening self-confidence and feeling happiness and satisfaction with performance of movements that pupils are asked to practice. (Ades and Katami 2000, p. 220)

\section{- Research problem:}

Although motor fluency is one of the important core abilities in (sports) motor creativity, but we clearly see that physical education curricula used in primary schools working to achieve educational goals and develop some physical abilities without took "enough" share to motor fluency programs. As primary education is the stage of starting to practice multi-sports activities that can build on it the high sports levels. Through field training supervision in primary schools, and getting through physical education and programs for all grades, especially first three; Researcher noticed that there is a lack of motor education programs followed in schools which led to ignore individual differences among students due to adherence to teach specific sports activities without taking into account needs and preferences of students. This is in addition to see lot of scientific studies' recommendations in motor education programs field (motor fluency - creative fluency), which recommended a review of primary grades students programs, also recommended to conduct scientific studies contain other programs may contribute to development of basic motor skills for students in early grades of primary education.

In the context of interest in motor fluency programs and their relationship with development of physical demands and basic motor skills many researchers turned to study this phenomenon; such as Amgad Mahdy and others (2012) where main results pointed out the effectiveness of the proposed program using motor stories on learning some handball introductory basic skills for pre-school children, El-Dewan and Osman (2012)) where one of its main results revealed the existence of significant differences between pre and post-measurements of motor, flexibility and originality fluency, Abdel Wahab (2011) where most important results were existence of significant differences between research groups in basic motor skills and educational objectives, Hassan (2005) where most important results pointed out the impact of the proposed motor fluency program on improving pupils performance in physical variables and basic motor skills, Efthimios (2003) where most important results availability of positive relationship between motor fluency and some psychological factors for pre-school children, and (Elsayed) (2001) which indicated that proposed motor fluency program has had an impact on developing some gymnastics motor.

Through review of previous studies content we can conclude that some studies focused on motor fluency programs and their impact on skills and fitness a positive correlation between the proposed programs and motor skills and physical performance requirements development.

\section{Research objectives:}

This research aims at:

1- To improve a motor fluency proposed educational program for second primary grade pupils.

2- To identify the effect of the proposed motor fluency program on improving some basic motor skills in physical education lesson.

\section{Research hypotheses:}

The current research seeks to validate the following hypotheses:

1- There are significant differences between pre and post-measurements' marks: means of The experimental group (which used the proposed motor fluency program) is in favor of post measurement

2- There are significant differences between pre and post-measurements' marks means of the control group (which used normal teaching program) in favor of post measurement.

3- There are significant differences between postmeasurements' marks means of experimental and control group in improving some basic motor skills in favor of experimental group.

4- Improvement differences in motor skills performance are in favor of the experimental group

\section{Research terms:}


Motor fluency program: "range of sporting activities in form of a coordination games featuring singles competition to improve motor skills for second primary grade pupils. (Procedural)

\section{Basic motor skills:}

They are those movements performed by the learner to realize his motor and body potentials and control it, i.e. move from one place to another, as well as skills of dealing with things or tools with his body limbs. (Abd alRahman)

\section{Research procedures:}

Research methodology: the experimental approach with two homogeneous experimental and control groups.

Research society and the sample: Research society consisted of the (204) second grade pupils from Mustafa Meshrefa evening primary school, Montazah educational department in the academic year 2012/2013; Research has been applied on (40) pupils randomly selected representing $(19.6 \%)$ of total research society, research sample were divided into two groups one experimental and the other control; each of them consisted of (20) pupils

\section{Data collection tools:}

1. Growth development rates indicators (age/year - Height/cm - Body weight / kg)

2. Physical abilities tests: The researcher referred to following scientific sources and studies: Abdel Wahab (2011), Saber (2006), Hassan (2005), Muhammad (2002) in order to identify and select the appropriate tests, namely: $2 \mathrm{~kg}$ medical ball forward pushing - 30m sprint from elongated start - trunk bend forward down from standing - Zigzag running (appendix 1)

3. Motor skills tests: The researcher referred to following scientific sources and studies: Abdel Wahab (2011), Kazem (2008), Mustafa (2000) and Al-Najjar (1999) in order to identify appropriate motor skills for this age category, as well as tests that measure it, namely: (measuring transitional movements) $25 \mathrm{~m}$ sprint test - long jump from stability - (measuring control skills) throwing hockey ball for most fare distance ball kicking test- throwing and snapping test Zigzag run (appendix 2)

\section{Tests reliability and validity:}

- Physical and skill tests validity: have been confirmed by applying the tests on two equal groups each of (10) pupils one is distinctive and the other is indistinctive in performance, there were statistical significant differences between the two groups at 0.05 level (appendix 3)

- Physical and skill tests validity: have been confirmed by using test/retest method with (5) days interval on (10) pupils not in the research sample. Pearson sample correlation between the two tests ranged between (0.75-0.91) which indicates tests reliability(appendix 3)

\section{Sample homogeneity:}

Distribution normality were checked and confirmed for some research variables which may have an impact on the experimental variable such as growth variables (age time height - and body weight), physical abilities and basic motor skills tests as illustrated by the following table:

Table (1) arithmetic mean, standard deviation, median and skewness coefficient $(\mathrm{n}=40)$

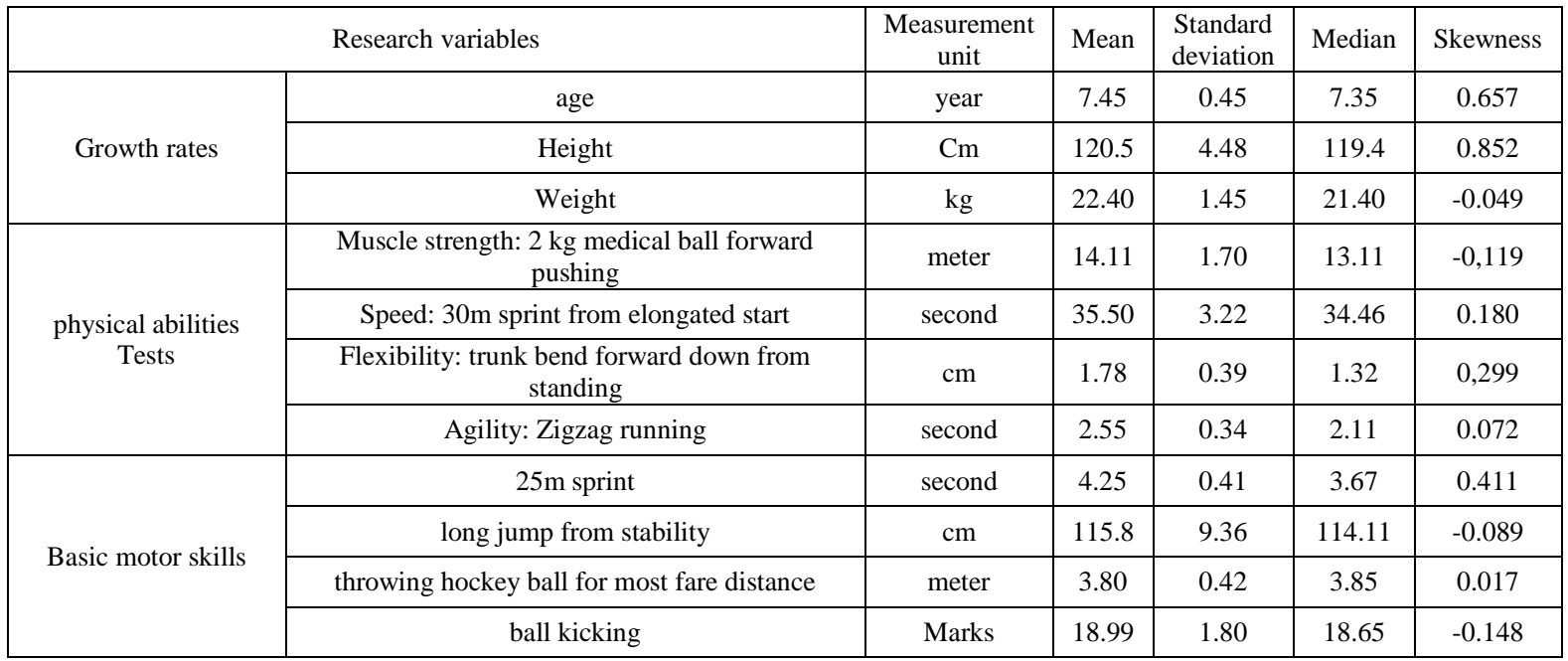




\begin{tabular}{|c|c|c|c|c|c|c|}
\hline \multicolumn{2}{|c|}{ Research variables } & $\begin{array}{c}\text { Measurement } \\
\text { unit }\end{array}$ & Mean & $\begin{array}{c}\text { Standard } \\
\text { deviation }\end{array}$ & Median & Skewness \\
\hline & throwing and snapping & marks & 30.92 & 2.39 & 30.91 & 0,231 \\
\cline { 2 - 8 } & Zigzag run & second & 11.60 & 1.40 & 11.51 & 0.245 \\
\hline
\end{tabular}

Table (1) results reveal that skewness values were between $(-0.148-0.852)$, which is between $( \pm 3)$. This confirms the distribution normality of all research variables. This gives also an indication that these data are free from abnormal distributions defects.

\section{Groups Equivalence:}

The following table illustrates experimental and control group's equivalence in all research variables.

Table (2) Differences significance between experimental and control groups in research variables

\begin{tabular}{|c|c|c|c|c|c|c|c|}
\hline & \multirow[t]{2}{*}{ Research variables } & \multirow[t]{2}{*}{$\begin{array}{l}\text { Measurement } \\
\text { unit }\end{array}$} & \multicolumn{2}{|c|}{$\begin{array}{c}\text { Experimental } \\
\text { Group } \\
(\mathrm{n}=20)\end{array}$} & \multicolumn{2}{|c|}{$\begin{array}{c}\text { Control } \\
\text { Group }(n=20)\end{array}$} & \multirow[t]{2}{*}{$\begin{array}{c}\mathrm{T} \\
\text { Value }\end{array}$} \\
\hline & & & Mean & SD & Mean & SD & \\
\hline \multirow{3}{*}{ Growth rates } & age & year & 7.43 & 0.41 & 7.49 & 0.47 & 0.229 \\
\hline & Height & $\mathrm{Cm}$ & 119.7 & 4.41 & 121.4 & 4.53 & 0.365 \\
\hline & Weight & $\mathrm{kg}$ & 22.29 & 1.39 & 22.51 & 1.49 & 0.401 \\
\hline \multirow{4}{*}{$\begin{array}{l}\text { physical abilities } \\
\text { Tests }\end{array}$} & $\begin{array}{c}\text { Muscle strength: } 2 \mathrm{~kg} \text { medical ball forward } \\
\text { pushing }\end{array}$ & meter & 14.18 & 1.62 & 4.09 & .71 & 0,134 \\
\hline & Speed: $30 \mathrm{~m}$ sprint from elongated start & second & 29.51 & 3.19 & 39.62 & 3.28 & 0.064 \\
\hline & $\begin{array}{l}\text { Flexibility: trunk bend forward down from } \\
\text { standing }\end{array}$ & $\mathrm{cm}$ & 1.84 & 0.34 & 1.73 & .43 & 0,172 \\
\hline & Agility: Zigzag running & second & 2.54 & 0.36 & 2.56 & 0.33 & 0.121 \\
\hline \multirow{6}{*}{ Basic motor skills } & $25 \mathrm{~m}$ sprint & second & 4.18 & 0.39 & 4.31 & 0.42 & 0.212 \\
\hline & long jump from stability & $\mathrm{cm}$ & 116.4 & 9.21 & 115.1 & 9.57 & 0.126 \\
\hline & throwing hockey ball for most fare distance & meter & 3.98 & 0.43 & 3.95 & 0.41 & 0.183 \\
\hline & ball kicking & Marks & 19.54 & 1.85 & 18.91 & 1.74 & 0.194 \\
\hline & throwing and snapping & marks & 30.75 & 2.42 & 31.14 & 2.36 & 0.274 \\
\hline & Zigzag run & second & 11.81 & 1.37 & 11.59 & 1.41 & 0.087 \\
\hline
\end{tabular}

T significant at 0.05 level $=2.04$

Table (2) results reveal that there are no statistically significant differences at 0.05 level between the two research groups in all variables

\section{The proposed motor fluency program: (appendix 5)}

\section{- Program's overall objective determination:}

Motor fluency program's overall objective has been determined as "identify the effectiveness of education using motor fluency on improving basic motor skills performance for second primary grade pupils..

Program developing foundations:

When developing the program; the researcher considered that content to be consistent with objectives, motor skills and physical abilities, as well as pupils' age stage characteristics. Researcher has taken into account also program activities diversity and starting from easy arriving to difficult. Researcher also taken into account that program content raise pupils' imagination through imitation activities, and be appropriate to human and material sources available during application, as well as considering individual differences among students during program content implementation.

\section{Educational program characteristics:}

The researcher took into account that proposed motor fluency program includes following elements (diversity of activity - Easy Performance - Continuity - Flexibility simple guidance.)

\section{Program's procedural objectives:}

The overall objective of the proposed motor fluency program in the form of procedural objectives could be 
observed, measured, and accurately described illustrating the different and expected performance forms and represented in cognitive, psychomotor and emotional objectives (appendix 5)

\section{Program Content components:}

Motor fluency program contents for grader primary pupils were determined by referring to El-Kholi and Rateb (1988), Al-Najjar (1999), Swedan (2000), Saber (2006), where all of them agreed that motor skills development or improvement for pupils during this age stage must include the: transitional movements (walking - running - jumping hopping) and control movements (ball rolling - ball throw over the shoulder - ball snapping - ball hitting - ball stopping - dribbling), References also indicated that motor fluency program content consists of three main aspects: "introductory games, acting movements, and cleverness movements", and these aspects include the follows: exercises: acting, dimensions leaning, color and direction perception, motor interconnection, exploratory exercises, introductory games and motor stories. All human and material resources to assist in program implementation were provided.

\section{Program Implementation general framework:}

- Program implementation on second primary grade pupils. .

- Program period is (8) weeks including (16) lessons

- Educational unit (Lesson) total time is (45) minutes distributed according to what followed in the school (5) minutes for primary part - (35) minutes for main part, which included (5) minutes animals movements imitation, (15) minutes for individual cleverness movements, and (15) minutes for cleverness movements with fellow - (5)minutes for ending part

- Educational content for basic motor skills explained to experimental group pupils using motor fluency, while directed motor activity is used with control group pupils. This to be done in the main part of the module.

- After program preparation it was presented to curricula and teaching methods experts to explore their opinion about the program validity to be applied on research sample (appendix 4)

\section{Main study:}

- Pre- measurements was conducted during the period from Sunday, February $12^{\text {th }}$ till the day Wednesday, February $15^{\text {th }}, 2013$ for both research group for (growth rates, physical abilities tests, and basic motor skills tests)

- Program Application: The program were applied during the period February $19^{\text {th }}$ to April $16^{\text {th }}, 2013$, The researcher has taught both experimental and control group with help from school's physical education teacher throughout the program period, which is nearly two months (eight weeks) includes (16 lessons) i.e. one lesson and its repetition in a week

- Post-measurements: After program implementation post measurements were conducted for both experimental and control group in basic motor skills tests (under discussion).

- Statistical methods: mean - standard deviation correlation coefficient - $\mathrm{T}$ test- improvement differences

\section{Results and discussion:}

Table (3) Significance of mean differences between pre and post measurements in basic motor skills tests of experimental group $(n=20)$

\begin{tabular}{|c|c|c|c|c|c|c|c|}
\hline \multirow{2}{*}{ Motor skills variables } & \multirow{2}{*}{$\begin{array}{l}\text { Measurement } \\
\text { unit }\end{array}$} & \multicolumn{2}{|c|}{ Pre-measurement } & \multicolumn{2}{|c|}{ Post-measurement } & \multirow{2}{*}{$\begin{array}{c}\text { Mean } \\
\text { differences }\end{array}$} & \multirow{2}{*}{$\begin{array}{c}\mathrm{T} \\
\text { Value }\end{array}$} \\
\hline & & Mean & SD & Mean & $\mathrm{SD}$ & & \\
\hline $25 \mathrm{~m}$ sprint & second & 3.91 & 0.38 & 3.41 & 0.27 & 0.5 & $7.81 * *$ \\
\hline long jump from stability & $\mathrm{cm}$ & 116.3 & 11.25 & 139.5 & 12.52 & 23.2 & $6.16 * *$ \\
\hline $\begin{array}{c}\text { throwing hockey ball for most fare } \\
\text { distance }\end{array}$ & meter & 4.12 & 0.27 & 5.22 & 0.46 & 1.1 & $11.73 * *$ \\
\hline ball kicking & Marks & 19.14 & 1.82 & 34.54 & 3.46 & 15.4 & $16.52 * *$ \\
\hline throwing and snapping & marks & 24.64 & 2.40 & 41.35 & 3.61 & 16.71 & $16.34 * *$ \\
\hline Zigzag run & second & 12.27 & 1.37 & 9.42 & 1.14 & 2.85 & $9.42 * *$ \\
\hline
\end{tabular}

* $\mathrm{T}$ significant at 0.05 level $=2.09$

$$
\text { ** } \mathrm{T} \text { significant at } 0.05 \text { level }=2.86
$$

Table (3) results reveal availability of significant differences at (0.01) level between pre and post measurements of motor skills for experimental group which undergone to the proposed program, where $\mathrm{T}$ value 
of "T" ranged between (6.16 -16.52). These differences are real impact of the proposed motor fluency program offering to students the motor resultant and also providing an opportunity for communication between pupils in the same age group by motor activity; which was founded on basic motor skills development such as running, jumping, ball throwing and snapping, ball kicking, and dribbling through diverse activities as animal movements imitation, individual cleverness movements, and cleverness movements with fellow, and others. All this helped to improve motor skills performance; also the program has had diversity of motor activities that are commensurate with motor performance requirements for this age stage. These results are consistent with results of Shaheen (1991), Abdullah (2002), and Hussein (2004) which indicated the positive effectiveness of motor fluency and education programs on motor skills development for children.

Table (4) Significance of mean differences between pre and post measurements in basic motor skills tests of control group $(\mathrm{n}=20)$

\begin{tabular}{|c|c|c|c|c|c|c|c|}
\hline \multirow{2}{*}{ Motor skills variables } & \multirow{2}{*}{$\begin{array}{c}\text { Measurement } \\
\text { unit }\end{array}$} & \multicolumn{2}{|c|}{ Pre-measurement } & \multicolumn{2}{|c|}{ Post-measurement } & \multirow{2}{*}{$\begin{array}{c}\text { Mean } \\
\text { differences }\end{array}$} & Value \\
\cline { 3 - 7 } & Mean & SD & Mean & SD & 0.25 & $3.36 * *$ \\
\hline $25 m$ sprint & second & 4.21 & 0.43 & 3.96 & 0.39 & 0.25 & 1.81 \\
\hline $\begin{array}{c}\text { long jump from stability } \\
\text { throwing hockey ball for most fare } \\
\text { distance }\end{array}$ & meter & 4.02 & 0.25 & 4.25 & 0.34 & 0.23 & $4.36 * *$ \\
\hline ball kicking & Marks & 19.78 & 1.73 & 21.04 & 2.03 & 1.62 & $2.12 *$ \\
\hline throwing and snapping & marks & 26.13 & 2.36 & 27.48 & 2.44 & 1025 & 1.87 \\
\hline Zigzag run & second & 12.33 & 1.41 & 10.56 & 1.06 & 1077 & $4.21 * *$ \\
\hline
\end{tabular}

* T significant at 0.05 level $=2.09$

** $\mathrm{T}$ significant at 0.05 level $=2.86$

Table (4) reveals that there are significant differences between pre and post measurements of some motor skills (25m sprint, throwing hockey ball for most fare distance, Zigzag run at 0.1 level, and ball kicking at 0.05 level) for control group which uses basic motor usual school motor activity, while there was no significant differences between pre and post measurements in long jump from stability, and ball throwing and snapping, as " $\mathrm{T}$ " value ranged between $(1.81$ - 4.36). Researcher attributes these results to that motor activities in traditional approach has included many of competitions activities that require fast movement and running and compete with others, and that prompted the control group pupils to their motor performance level in walking, running and dribbling, which illustrated by differences pre and post measurements in the results of 25 meters sprint, Zigzag running. Researcher also attributes the differences between pre and post measurement in throwing hockey ball for most fare distance to pupils tendency to motor activity that requires playing balls, especially balls that hold in the hand, which requires ability to throw the ball to a certain goal or throw the ball to fellow which helped to increase the throwing distance during the test of throwing hockey ball for most fare distance, and thus improve the throwing performance as one of basic element of motor skills, while the non existence of statistically significant differences between pre and post measurements in long jump from stability is due to that directed motor activity does not concern with muscle strength development during this age group; which negatively affect legs muscle power development, which in turn led to failure of pupils' jump from stability ability, and then lack of jump level improvement, and this is confirmed by Abdullah (2002) who mentioned that motor activity dramatically increase within pupils at first age group at primary school, motor problems appear clearly within them, through movement, games and multifaceted sports practice, and ignoring identifying those motor problems during this stage means neglecting identifying pupils' motor skills development's naure, these results are consistent with results of AbdelWahab (2011) Hassan (2005), Hussein (2004) and Mustafa (2000), which indicated the effectiveness and of motor activities on improving motor skills and abilities in children in early years. 
Table (5) Significance of mean differences between post measurements in basic motor skills tests of experimental and control group

\begin{tabular}{|c|c|c|c|c|c|c|c|}
\hline \multirow{2}{*}{ Motor skills variables } & \multirow{2}{*}{$\begin{array}{l}\text { Measurement } \\
\text { unit }\end{array}$} & \multicolumn{2}{|c|}{$\begin{array}{l}\text { Experimental } \\
\text { group (n-20) }\end{array}$} & \multicolumn{2}{|c|}{$\begin{array}{l}\text { Control group } \\
(n=20)\end{array}$} & \multirow{2}{*}{$\begin{array}{c}\text { Mean } \\
\text { differences }\end{array}$} & \multirow{2}{*}{$\begin{array}{c}\mathrm{T} \\
\text { Value }\end{array}$} \\
\hline & & Mean & SD & Mean & SD & & \\
\hline $25 \mathrm{~m}$ sprint & second & 3.41 & 0.27 & 3.96 & 0.39 & 0.55 & $3.62 * *$ \\
\hline long jump from stability & $\mathrm{cm}$ & 139.5 & 12.52 & 118.2 & 10.18 & 21.3 & $3.32 * *$ \\
\hline throwing hockey ball for most fare distance & meter & 5.22 & 0.46 & 4.25 & 0.34 & 0.97 & $6.15 * *$ \\
\hline ball kicking & Marks & 34.54 & 3.46 & 21.04 & 2.03 & 13.5 & $12.73 * *$ \\
\hline throwing and snapping & marks & 41.35 & 3.61 & 27.48 & 2.44 & 13.57 & $11.31 * *$ \\
\hline Zigzag run & second & 9.42 & 1.14 & 10.56 & 1.06 & 1.14 & $4.58 * *$ \\
\hline
\end{tabular}

* $\mathrm{T}$ significant at 0.05 level $=2.03$

** T significant at 0.05 level $=2.71$

Table (5) results point out the existence of statistically significant differences at (0.05) level between post measurements for experimental and control group in all basic motor skills and in favor of the experimental group, where $\mathrm{T}$ value ranged between (3.32 and 12.73). It is possible to return excellence of proposed motor fluency program on directed motor activity program to that various activities of motor fluency program like animal movement imitation from walking and running, control skills, sequence skills, and introductory games helped pupils to enjoy those motor skills through activities that depend on motivation and directed excitement and that positively helps on motor skills learning speed. These results are also due to the positive effect of motor fluency program, which contributed effectively to positive tendency to take into account children trends and the needs to play and work to stimulate all senses in the educational process as well as giving them a positive role during learning, which helped to support and increase their motivation to learn.

It is also possible to attribute the differences between experimental group and control group in ball kicking to that this skill is in the motor fluency program content and there were variety of many exercises that helped to develop it better than directed motor activity program in the control group, which did not have the opportunity to practice as the experimental group. Motor fluency program exercises stressed on reaching mastery level of this skill compared with motor activity program, which rely on the practice by some small games. Experimental group exceeded control group in throwing and snapping movements even that control group pupils practiced activities include throwing and snapping. This experimental group superiority due to motor experiences included in motor fluency program which contributed to upgrading throwing and snapping performance level, and in turn had a positive effect on experimental group superiority. These findings are consistent with results of Abdel-Wahab (2011), Hassan (2005), Hussein (2004), Kamal (2003), and Fathi (2003), which indicated that motor fluency and education programs have positive and effective impact on motor skills improvement and development better than the motor activities followed in school programs, which may be in directed form.

Table (6)

improvement differences between pre and post measurements in motor skills tests for experimental and control groups

\begin{tabular}{|c|c|c|c|c|c|c|c|c|}
\hline \multirow{2}{*}{$\begin{array}{c}\text { Motor skills } \\
\text { variables }\end{array}$} & \multirow{2}{*}{$\begin{array}{l}\text { Measurement } \\
\text { unit }\end{array}$} & \multicolumn{2}{|c|}{$\begin{array}{l}\text { Experimental } \\
\text { group }(\mathrm{n}-20)\end{array}$} & \multirow{2}{*}{$\begin{array}{c}\text { Improvement } \\
\%\end{array}$} & \multicolumn{2}{|c|}{$\begin{array}{l}\text { Control group } \\
(\mathrm{n}=20)\end{array}$} & \multirow{2}{*}{$\begin{array}{c}\text { Improvement } \\
\%\end{array}$} & \multirow{2}{*}{$\begin{array}{l}\text { Improvement } \\
\text { difference }\end{array}$} \\
\hline & & $\begin{array}{c}\text { Pre } \\
\text { Measurement }\end{array}$ & $\begin{array}{c}\text { Post } \\
\text { measurement }\end{array}$ & & $\begin{array}{c}\text { Pre } \\
\text { Measurement }\end{array}$ & $\begin{array}{c}\text { Post } \\
\text { measurement }\end{array}$ & & \\
\hline $25 \mathrm{~m}$ sprint & second & 3.91 & 3.41 & 12.79 & 4.21 & 5.94 & 3.96 & 6.85 \\
\hline $\begin{array}{c}\text { long jump } \\
\text { from stability }\end{array}$ & $\mathrm{cm}$ & 116.3 & 139.5 & 19.95 & 114.46 & 3.27 & 118.2 & 16.68 \\
\hline $\begin{array}{c}\text { throwing } \\
\text { hockey ball } \\
\text { for most fare } \\
\text { distance }\end{array}$ & meter & 4.12 & 5.22 & 26.70 & 4.02 & 5.72 & 4.25 & 20.98 \\
\hline ball kicking & Marks & 19.14 & 34.54 & 80.46 & 19.78 & 6.37 & 21.04 & 74.09 \\
\hline $\begin{array}{c}\text { throwing and } \\
\text { snapping }\end{array}$ & marks & 24.64 & 41.35 & 67.82 & 26.13 & 5.17 & 27.48 & 62.65 \\
\hline Zigzag run & second & 12.27 & 9.42 & 23.23 & 12.33 & 14.36 & 10.56 & 8.87 \\
\hline
\end{tabular}


Table (6) results reveal that experimental group improvement percentage between motor skill tests pre and post measurements which ranged between (12.79\% $80.46 \%$ ), exceeded those of control group which ranged between $(5.17 \%$ - 14.36\%), while the improvement differences were in favor experimental group and ranged between $(6.85 \%-74.09 \%)$. Table results also illustrates that highest improvement percentage in experimental group was $(80.46 \%)$ in ball kicking test. This is due to the positive effect of the motor fluency program in acquiring motor experiences to experimental group through practice for many activities that have helped to improve motor skills (under discussion) performance, while the lowest improvement percentage in experimental group was $(12.79 \%)$ in the 25 meter sprint test, this is due to the fact that the transitional speed development rate is slower than other motor skills for pupils in research sample. Same table results indicate that the highest improvement rate for control group was (14.36\%) in Zigzag run test. This is due and due to the fact that motor activity acquire an individual motor flow, coordination, proper sense of directions and distances, and relax ability, while the lowest improvement percentage in the control group was $(5.17 \%)$ in throwing and snapping test. This reflects control group pupils weak ability to snap balls even they are able to throw it to specific distances, Improvement rates differentials in favor of experimental group are due to that proposed motor fluency program is characterized by motor experiences directed to develop basic motor skills.

\section{Conclusions:}

In light of the research objectives and results the following could be concluded:

- There are statistically significant differences between pre and post measurements in all motor skills in favor of post measurements for experimental group that follow the proposed motor fluency program.

- There are statistically significant differences between pre and post measurements in some motor skills in favor of post measurements for control group (25 meter sprint, throwing hockey ball for most fare distance, ball kicking, zigzag run)

- There were no statistically significant differences between pre and post measurements in some motor skills for control group pupils (long jump from stability, throwing hockey ball for most fare distance, zigzag run)
- There are statistically significant differences between post measurements in all motor skills for experimental and control group pupils in favor of experimental group

- Improvement percentage differences were in favor of the experimental group pupils that follow the proposed motor fluency program

\section{Recommendations:}

In the light of research results, researcher recommends the following:

- Proposed motor fluency educational program to be generally applied for physical education lessons for second grade primary students.

- Conducting similar studies in the field of motor fluency on primary school students linking it with various motor activities that are commensurate with pupils' age stage.

\section{References:}

1. Abdullah, Ahmed Abdel Azim (2002): The effect of motor education program using small recreational games on some motor variables and motor satisfaction for (6: 9) years children, Ph.D., Faculty of Physical Education for Men, Helwan University . (In Arabic Language)

2. Kamal, Edward Alphonse (2003): the effect of proposes motor education program on motor cognitive efficiency level for pre-school children, Ph.D., Faculty of Physical Education for Men, Zagazig University . (In Arabic Language)

3. Rateb, Osama Kamel (1999): motor development, Entrance to integrated, Dar Elfeker El-Arabi, Cairo. (In Arabic Language)

4. Mahdi, Amjad Hammadi Jassim and Hammadi Thaera (2012): The impact of proposed educational program using motor stories on learning some handball introductory basic motor skills for preschool children, Physical Education journal, Issue 1, Iraq . (In Arabic Language)

5. El-Kholi , Amin and Rateb, Osama: (1988): Motor Education, 2nd ed, Dar Elfeker El-Arabi, Cairo . (In Arabic Language)

6. Mohammed, Khalil Moawad (2003): Talented capabilities and features, field study, Dar Elfekr ElArabi, Alexandria. (In Arabic Language) 
7. Swedan, Salem Abdul-Latif, (2000): teaching physical education for primary school students, Moltaka ElFekr, Alexandria . (In Arabic Language)

8. Muhammad, Taher Darwish (2002): the effect of motor education program on some basic motor abilities and physical characteristics variables of pre-school children (4-6 years), Physical Education journal, vol.11, issue 4, Faculty of Physical Education, Iraq . (In Arabic Language)

9. Al-Samarrai, Abbas and Al-Samarrai Abdulkarim (2001): Teaching competencies in physical education teaching methods, Dar al-Hikma Press, Basra, Iraq. (in Arabic Langualge)

10.Ades. Abdul Rahman and Katami, Nayef (2000): Principles of Psychology, $1^{\text {st }}$ ed. Dar Elfeker for printing, publishing and distribution, Amman, Jordan. (In Arabic Language)

11.Al-Najjar, Abdel-Wahab (1999): Basic motor skills for primary school students, Saudi Federation of Physical Education and Sports, Riyadh . (In Arabic Language)

12.Kazem, Faten Ismail: (2008): The effect of motor education program on some motor variables, Faculty of Basic Education journal, Mustansiriya University, Iraq

13.Saber, Fatima Awad (2006:) Motor education and its applications, Dar ElWafaa for printing and publishing, Alexandria . (In Arabic Language)

14.El-Dewan, Lamia and Osman, Intsar (2012): The impact of teaching small games using brainstorming, Reciprocal and demonstration methods on development some motor creative abilities, online published research: www.iasj.net . (In Arabic Language)

15.El-Dewan, Lamia(1999): The effect of using two teaching methods on developing creative and motor abilities in physical education lesson, Ph.D., Faculty of Physical Education, Basra, Iraq . (In Arabic Language)

16.Hussein, Mohamed Fathi (2004): The effect of motor education program on some motor skills performance for (6-9) years deaf and dumb, $\mathrm{PhD}$, Faculty of Physical Education, Mansoura University. (In Arabic Language)

17.Shaheen, Madiha Hassanein (1991): the basic movements and its performance level of pre-school stage, Master Thesis, Faculty of Physical Education for Girls, Zagazig University . (In Arabic Language)

18.Abdel Wahab, Maha Mohamed (2011): motor fluency educational program and its effectiveness on some basic motor skills and some educational objectives in physical education lesson, Ph.D., Faculty of Physical Education for Girls, Zagazig University . (In Arabic Language)

19.Ibrahim, Maytham Latif (2008): motor fluency programs objectives available online: www.forum.lragacad.org . (In Arabic Language)

20.Abd al-Rahman, Nora Ali (2012): Basic motor skills and physical activity. Available online at: .www.arar.facebook.com

21.Hassan, Halla Fayez (2005): The impact of motor fluency program on developing physical fitness and basic skills for fifth primary grade pubils, Master thesis, faculty og Physical Education for Girls, Helwan University . (In Arabic Language)

22.Fathi, Hani Mohammed (2003): The effect of proposed motor education educational program on raising some motor fitness components for primary school pupils, Master Thesis, Faculty of Physical Education, Mansoura University . (In Arabic Language)

23.El-Sayed, Hoveyda Fathi (2001): the effect of proposed motor fluency program on developing some motor skills in gymnastics and motor satisfaction for kindergarten, Ph.D. thesis, Faculty of Physical Education for Girls, Zagazig University. (In Arabic Language)

24.Mustafa, Wael Salama (2000): The effect of motor education program on some basic skills and cognitive elements for first primary grade schools pupils, Master Thesis, Faculty of Physical Education, Al-Fateh University, Libya

25.Abdul Hussein , Yaareb Khyoun (1994): The effect of proposed play field in the development of some physical and motor abilities for (7-10 years)age, Ph.D, Faculty of Physical Education, University of Baghdad . (In Arabic Language)

26.Efthimios, Trevlas (2003): Relationship between playfulness and motor creativity in preschool children , journal of Early child Development and care, $\mathrm{V}, 173$, issue, 5 
